\title{
Beech-mast crop evaluation in Kněhyně forest complex (Beskydy Mts. Czech Republic) as a food supply for granivorous rodents
}

\author{
M. Heroldová1, J. Suchomel ${ }^{2}$, L. Purchart ${ }^{2}$, L. Čepelka ${ }^{2}$ \\ ${ }^{1}$ Institute of Vertebrate Biology, AS CR, Květná 8, 60365 Brno, Czech Republic, e-mail: heroldova@ivb.cz; \\ ${ }_{2}^{2}$ Institute of Forest Ecology, Mendel University in Brno, Zemédèlská 3, 61300 Brno, Czech Republic, \\ e-mail:suchomel@mendelu.cz
}

\begin{abstract}
Heroldová M., Suchomel J., Purchart L., Čepelka, L. 2009: Beech-mast crop evaluation in Kněhyně forest complex (Beskydy Mts. Czech Republic) as a food supply for granivorous rodents. - Beskydy, 6 (1): 27-32

Good beech-mast crop is important not only for beech forest regeneration but it stimulates population abundances of granivorous animals. Abundant beech-mast crop was observed in autumn 2011 in Beskydy Mts. Mean mass of healthy beech-mast on Kněhyně Mts complex was $92 \mathrm{~g} \cdot \mathrm{m}^{-2}$ which represents 390 pieces $(\mathrm{pc}) / \mathrm{m}^{2}$. That was why diet supply for granivorous forest rodents, in means of current biomass of beechmast, was ascertained in 5 beech stands. At each locality, beech stands were chosen to represent Kněhyně Mt. beech forests and differ in age structure and the elevation. Biomass of beech-mast crop collected from the lowest elevation ( $5^{\text {th }}$ vegetation tier) was higher (as to number of beechnuts $/ \mathrm{m}^{2}$ ) and heavier $\left(\mathrm{g} / \mathrm{m}^{2}\right)$ compared to the highest elevation one ( $8^{\text {th }}$ vegetation tier). The beech forests from the lower altitude may have a better condition for the beech seeds production. As the granivorous species are peeling the beechnuts, so the peeled diet supply of beech-mast was also stated. This should be considered if calculating diet consumption of particular rodent species.
\end{abstract}

Key words: beech mountain forests, biomass of beechnuts harvest, diet supply for granivorous species

\section{Introduction}

In autumn 2011, abundant beech-mast crop (seeds of European beech, Fagus sylvatica L.) was noted in the area of the Beskydy Mts. The positive effect of good mast crops is in increase of natural regeneration of beech but it also stimulate populations of granivorous species especially rodents to increase its densities (Pucek et al. 1993; Jensen 1982). These species respond sensitively to good food supply and in case of abundant mast they might reproduce even in winter (Zejda 1962). Outbreaks occurred in two dominant forest species as bank vole (Myodes glareolus (Pallas)) and yellow-necked mouse (Apodemus flavicollis (Mel.)) only in years following huge seed production (Jensen 1982, 1985; Jensen and Nielsen 1985; Suchomel and Heroldová 2008). Together with other species of seed consumers these were able to liquidate considerable part of the tree seed production (Crawley 1992). For winter season, rodent species collect food reserves. Mice are able to collect as much as $4 \mathrm{~kg}$ of seeds (Jensen 1982). The typical burial site was a few centimeters below the soil surface in the wall of a rodent runway. Burial of seeds led to higher germination, as seeds deposited in the litter layer were killed by frost or drought. Not all seeds are consumed and seedlings are often found in clusters originating from caches. Mice species are able to migrate to long distances and concentrate where food occurs and disperse the seeds. Seeds of beech were removed by rodents and cached at 1-13 $\mathrm{m}$ (mean $4.13 \mathrm{~m}$ ) distances from the point of falling (Jensen and Nielsen 1985). In good mastyears rodents manage to remove not more than $15-20 \%$ of the beech-mast harvest (Tanaka 1995) 
and by Skrzydlowski (2001) damage of seeds is 10times lower if compared to low harvest when almost all beech-mast may be removed. This was in dependence on the quantity and the quality of the beech-mast harvest.

The aim of our study was to evaluate the beech-mast crop in various elevations of the Kněhyně Mts complex. The differences in the size of particular mast crops as well as variability of the size of seeds were compared. Granivorous rodents density response was also expressed. As these rodents peel the seeds of beech before consuming, the real diet supply of the peeled beech-mast was also evaluated.

\section{Material and methods}

As to find out diet supply for granivorous forest rodents, current biomass of beech-mast was ascertained in five beech stands. At each locality, beech stands were chosen to be close to the small mammal species monitoring plots and differ in age structure and the elevation. In ten of plots, all samples of beech-masts were collected from the ground from randomly spread $0.25 \mathrm{~m}^{2}$ plots. Beech-mast was counted and sound seeds were selected from those damaged by insects and weighed. The individual seeds in various localities were weighed to know its mass variability. Compared was the weight of beechnuts of the $5^{\text {th }}$ vegetation tier with that of $8^{\text {th }}$ vegetation tier. As the granivorous species are peeling the beechnuts, so the real diet supply mass was also stated.

Small mammal species were collected by snap-trapping in cultivated stands of fruiting European beech (F. sylvatica) on southern slope of Malá Stolová Mt.(49³0'19.5”N $\left.18^{\circ} 18^{\prime} 46.0^{\prime \prime} \mathrm{E}\right)$, with dominant Calamagrostis arundinacea (L.) Roth in the undergrowth, at altitude $940 \mathrm{~m}$. The relative abundance of granivorous species as bank vole and yellow-necked mouse was calculated according to Losos et al. (1984).

All statistical evaluations were done in Statistica for Windows (StatSoft Inc.).

\section{Results and discussion}

In autumn 2011, abundant harvest of beechmast was evaluated as to the current biomass (diet supply for rodents). Mean biomass of healthy beech-mast was 92 g.m-2 which represents 390 pieces $(\mathrm{pc}) / \mathrm{m}^{2}$ of beech-mast. Five old fruiting beech stands varying in elevation were evaluated (Fig. 1). Good beech-mast harvests were continuously monitored at this forests complex and compared. In autumn 2007 the beech-mast harvest was also evaluated in the similar sides with mean biomass being much lower (23.23 g.m-2; Heroldová et al. 2008). Great differences were found also in rate of empty and wormy seeds to healthy and full one. In 2011 this rate was 12 to 88, but in 200720 to 80 . Also in 1999, similar monitoring was done in two

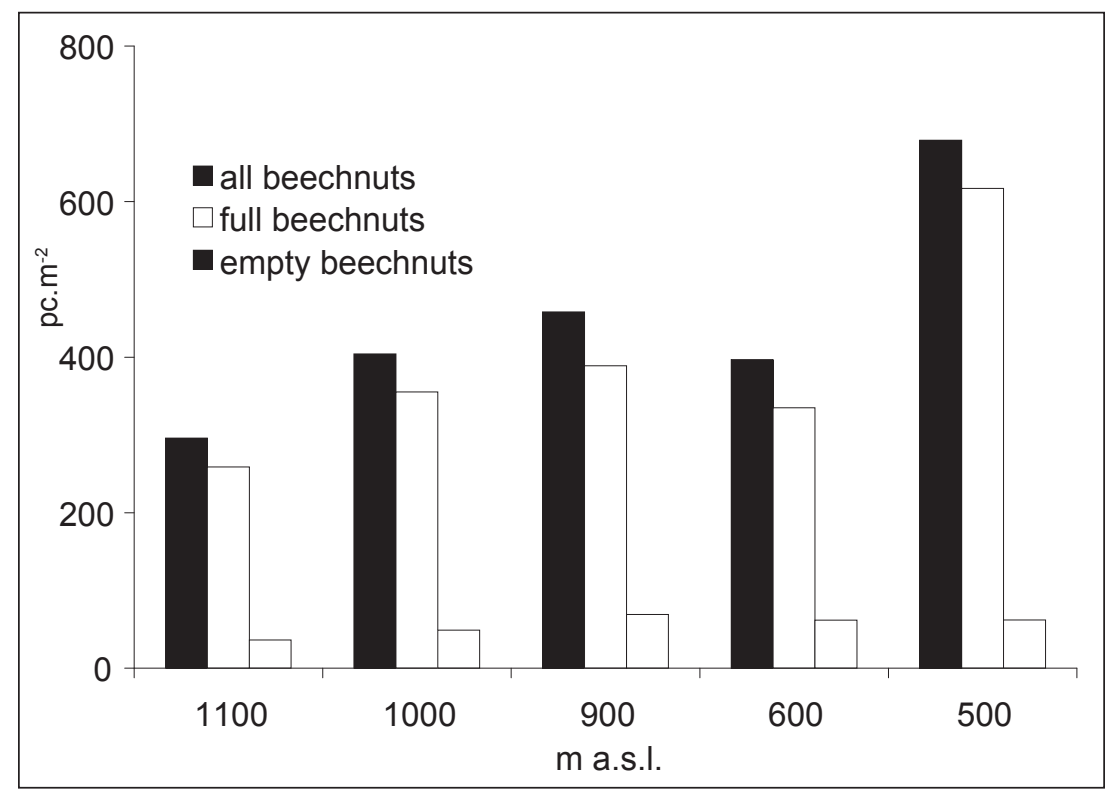

Fig. 1: Biomass of beech-mast harvest $\left(p c . m^{-2}\right)$ in five beech forests of various elevations in Knèhyně complex (Beskydy Mts.). 
forests at the same locality and produced much less biomass of seeds (mean 10 g.m² ${ }^{-2}$, Bryja et al. 2001).

Even if the harvests of beech-mast were variable in size they always influenced the dynamic of the granivorous mammal species and stimulated their densities (Jensen 1982; Suchomel et al. 2007; Heroldová et al. 2008). Monitoring of rodent species was done in one of the beech complex on Malá Stolová Mt. which resulted in increase of bank vole and yellow-necked mouse densities the year following the mast year (Fig. 2).
In autumn 2011 the highest biomass of beechmast was in old beech forest of 5 th vegetation tier (VT; Fig. 1). Even there was a great variability of the seed weight, lowest elevation data $\left(5^{\text {th }}\right.$ VT) were compared to $8^{\text {th }}$ VT. The 300 beech seeds of each were randomly chosen. As the normal distribution of data, these were compared by ttest. Fig. 3 shows the main data of both sets. Of significantly higher weight were the seeds of the lower VT $(\mathrm{t}=5.02 ; \mathrm{df}=299, \mathrm{p}<0.001)$. It means the lower elevation beech forests had a better condition for the beech seeds production.

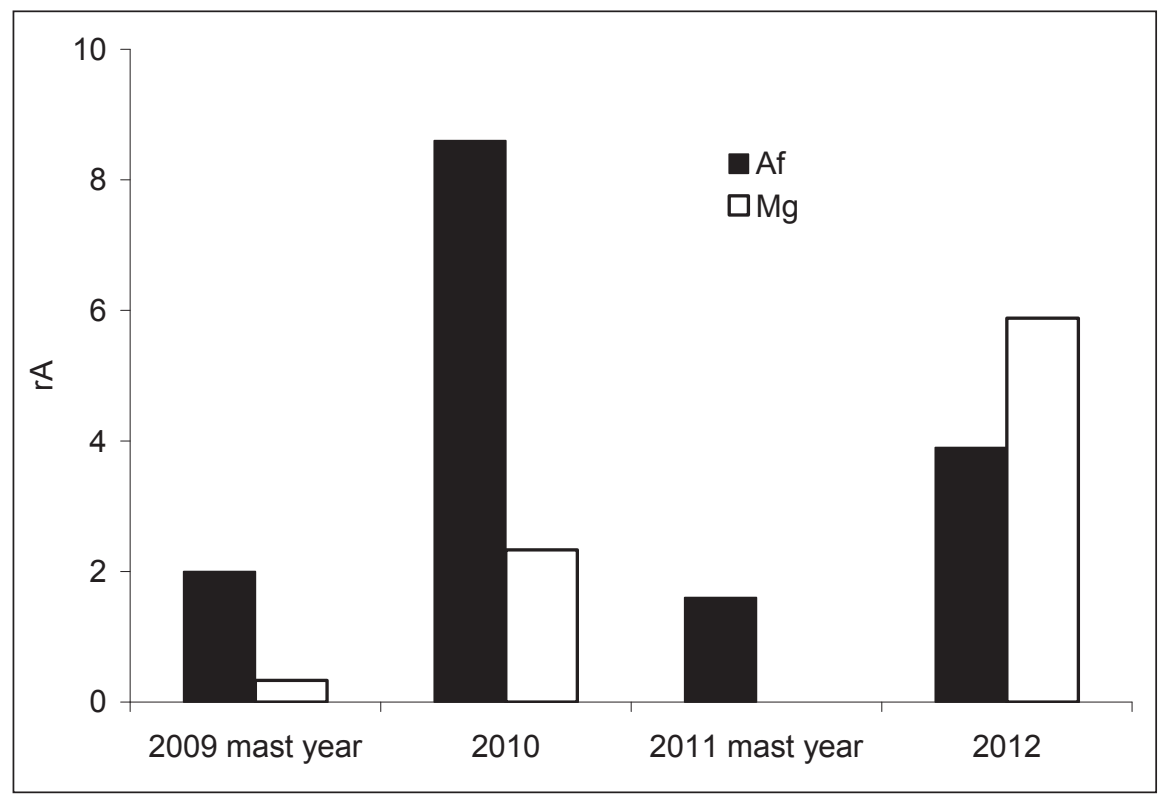

Fig. 2: Dynamic of two granivorous species in beech forest in Kněhyně Mts complex under influence of beech-mast years. Af-Apodemus flavicollis, $\mathrm{Mg}$ - Myodes glareolus.

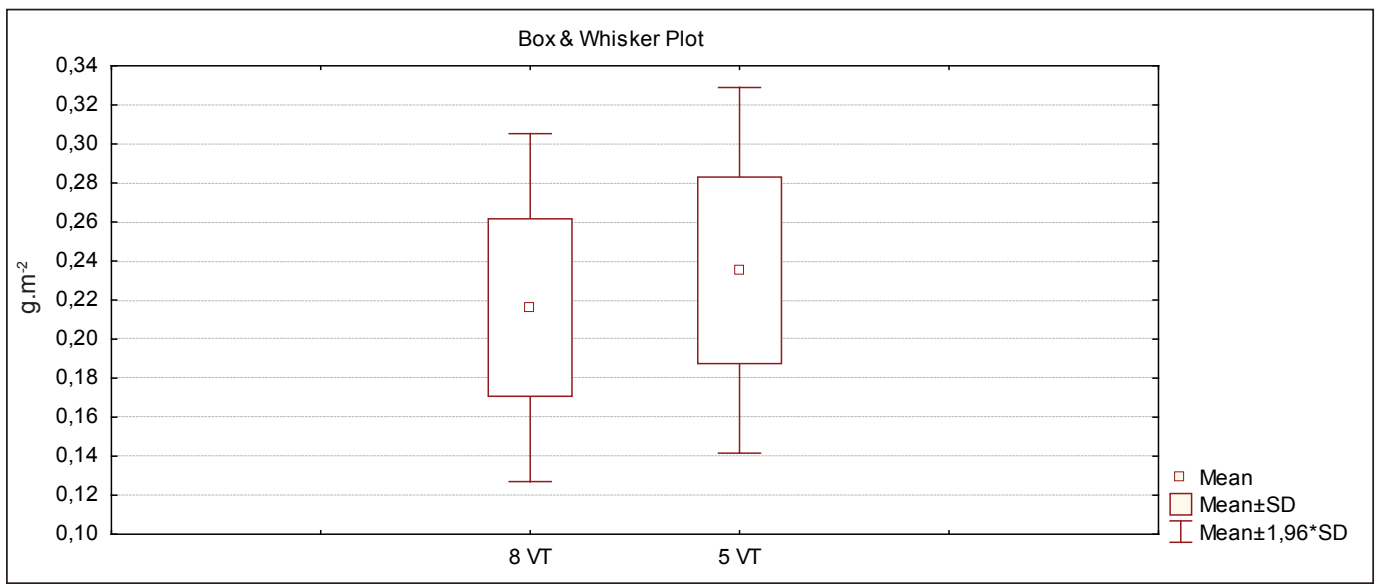

Fig. 3: Biomass of beech-mast harvest $\left(g . m^{-2}\right)$ in two beech forests from $8^{\text {th }}$ and $5^{\text {th }}$ vegetation tier in Knèhyně Mts. forest complex. 


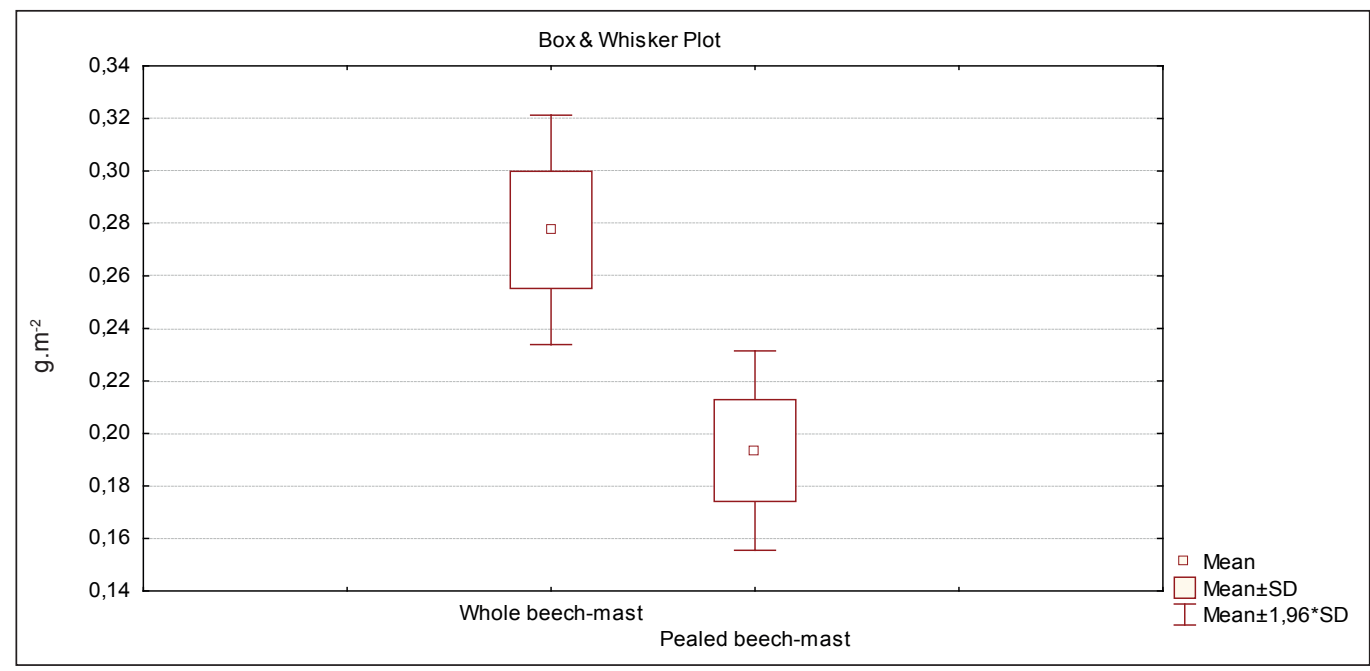

Fig. 4: Weight of peeled beech-mast as a food supply for rodents compared to whole beech-mast.

Rodent species eat the beech-mast peeled, removing the shell. Weight of peeled beech-mast as a food supply for rodents was compared to whole beech-mast (Fig. 4). Peeled beech-mast form $69.78 \%$ of the whole one. It means about $30 \%$ of beech-mast is not consumed by rodents.

Natural forest regeneration by means of tree seeds can be strongly influenced due to the seed and fruit consumption by small granivorous rodent species. Yellow-necked mouse autumn diet analyses show strong dominance of seeds (Bryja et al. 2001). In autumn with beech-mast available this was the dominant item, in some individuals being the only food. By Obrtel, Holišová (1974), Holišová, Obrtel (1980), Burschel et al. (1992), Heroldová (1994) and Bryja et al. (2001) diet preferences of yellow-necked mouse for seeds are the similar during the whole year and in all studied biotopes (lowland forests, spruce monoculture, small isolated woods and mountains forests). As to bank vole diet in autumn, Holišová (1971) stated that this species influences the natural forest regeneration by high consumption of tree seeds. The increased abundance of both dominant forest species (bank vole and yellow-necked mouse) can result in important losses of seeds of forest trees. Many other vertebrates as, for example birds and ungulates, may show negative impact on the natural regeneration of beech forest by beech-mast predation (Skrzydlowski 2001).

\section{Conclusion}

Population dynamic of small granivorous species of rodents is strongly influenced by good crop of forest tree seeds. The average biomass of beech-mast in our study was very high (92 g.m-2 which represents 390 pc.m ${ }^{-2}$ of beech-mast) in autumn 2011. In respond on this granivorous species aroused its densities. It was found the biomass of the beech-mast harvests in this region was increasing. Also the seed year frequency increased. By Övergaard et al. (2007), climatic changes, especially an increasing temperature, may have been responsible for the higher frequency of mast years, but increased atmospheric nitrogen deposition may also have been a contributory factor. In mast year an increase of population density was ascertained also in herbivorous vole species, even if the beech-mast was out of their reach and not consumed (Heroldová et al. 2012). In mast year, even the other biomass of plants can be of a higher quality. Overwintering population of voles, in a good condition, may cause damage to the bark of young beech trees. By Homolka et al. (2011) the biomass of autumn food supply (in terms of seed crop) was a good predictor of bark damage. Seed years in forests seem to have a key role not only in forest regeneration but also in influencing dynamic of many forest animal species from insects to deer.

\section{Acknowledgements}

The paper was supported by financial means of the NAZV QH72075 and MSM 6215648902. 


\section{References}

Bryja, J., Heroldová, M., Jánová, E. 200l: Vliv drobných zemních savců na obnovu lesa $\mathrm{v}$ NPR Kněhyně - Čertův mlýn (Influence of small mammals on forest regeneration in National Nature Reserve Kněhyně - Čertův mlýn). Beskydy, 14: 189-200 (in Czech).

Burschel, P., El Kateb, H., Monsandl, R. 1992: Experiments in mixed mountain forest in Bavaria. In: Kelty, M.J., Larson, B.c., Oliver C.D. (eds.) Forestry science. The ecology and silviculture of mixed species forests. Dordrecht, Boston, London, Kluwer Academic Publishers, 183-215.

Crawley, J.M. 1992: Seed predation and plant population dynamics. In: FenNer, M., (ed.), The ecology of regeneration in plant communities. Blackwell Science, Oxford, p. 157-192.

HeroldovÁ, M. 1994: Diet of four rodent species from Robinia pseudoacacia stands in South Moravia. Acta Theriologica, 39: 333-337.

Heroldová, M., Bryja, J., Jánová, E., Suchomel, J., Homolka, M. 2012: Rodent damage to natural and replanted mountain forest regeneration. The Scientific World Journal, vol. 2012, Article ID 872536, 6 pages, 2012. doi:10.1100/2012/872536.

Heroldová, M., Suchomel, J., Purchart, L., Homolka, M. 2008: The role of granivorous rodents in beech forest regeneration in the Beskydy Mts. (Czech Republic). Beskydy. 1: 131-134.

HoLišová, V. 1971: The food of Clethrionomys glareolus at different population densities. Actasc. Nat. Brno, 5: 1-34.

Holišová, V., OBRTEL, R. 1980: Variation in the trophic niche of Apodemus flavicollis in two different habitats. Folia Zoologica, 29: 33-41.

Homolka, M., Heroldová, M., Kamler, J. 201l: Plant biomass and prediction of debarking caused by rodents on artificial regeneration of forest stands. In: JAсов, J., Esther, A. (eds.): Julius-Kün-Archive, 8th European Vertebrate Pest Management Conference, Berlin, Germany, 26-30.

JENSEN, T.S. 1982: Seed production and outbreaks of non-cyclic rodent populations in deciduous forests. Oecologia, 54: 184-192.

JENSEN T.S. 1985: Seed predator interactions of European beech Fagus sylvatica and forest rodents Clethrionomys glareolus and Apodemus flavicollis. Oikos, 44: 149-156.

Jensen, T.S., Nielsen, O.F. 1985: Rodents as seed dispersers in a heath - oak wood succession. Oikos, 44: 149-156.
Losos, B., Gulicka, J., Lellák, J., Pelikán, J. 1984: Ekologie živočichü. [Ecology of animals]. SPN, Praha, 316 pp.

Övergaard, R., Gemmel, P., Karlsson, M. 2007: Effects of weather conditions on mast year frequency in beech (Fagus sylvatica L.) in Sweden. Forestry, 80: 555-565.

Obrtel, R., Holišová, V. 1974: Povaha potravy Apodemus flavicollis a Clethrionomys glareolus v lužním lese )The food of Apodemus flavicollis and Clethrionomys glareolus in a lowland forest). Lynx, 16: 37-45 (in Czech).

Pucek, Z., Jędrzejewski, W., Jędrzejewska, B., Pucek, M. 1993: Rodent population dynamics in a primeval deciduous forest (Białowieża National Park) in relation to weather, seed crop, and predation. Acta Theriol, 38: 199-232.

SKRZYDLOWSKI, T. 2001: The impact of rodents on natural regeneration of tree and shrubs in forest communities. Sylwan, 12: 93-102.

StatSoft Inc. 2012: Electronic Statistic Textbook, Tulsa, OK: StatSoft, http://www.statsoft.com/ textbook/stathome.html. Accessed 20 December 2012.

Suchomel, J., Heroldová, M. 2008: Effect of seed crop of trees on the abundance and body parameters of granivorous small mammals in isolated forest stands of southern Moravia (Czech Republic). Polish Journal of Ecology, 56: 155-160.

Suchomel, J., Heroldová, M., Purchard, L. 2007 : The study of changes in the synusia of small terrestrial mammals (Insectivora, Rodentia) of top parts of the Beskids (preliminary results). Beskydy, 20: 211-216.

TANAKA, H. 1995: Seed demography of three co-occurring Acer species in Japanese temperate deciduous forest. Journal of Vegetation Science, 6: 887-896.

ZEJDA, J. 1962: Winter breeding of the bank vole (Clethrionomys glareolus Schreb.) in a peak year. Zoologickélisty, 11: 309-321. 
